\title{
The Importance of Silver Nanoparticles in Human Life
}

\author{
Sh.Ahmadi* \\ Department of Science, Payame Noor University (PNU), Tehran, Iran \\ Received: 07/01/2020 Accepted: 27/01/2020 Published: 20/03/2020
}

\begin{abstract}
One of the nanomaterials which having an early impact in health care product is nano-silver. Silver has been used for the treatment of medical ailments for over 100 years due to its natural antibacterial and antifungal properties. The nano silver particles typically measure $25 \mathrm{~nm}$. They have extremely large relatively surface area, increasing their contact with bacteria or fungi, and vastly improving its bactericidal and fungicidal effectiveness. The nano silver when in contact with bacteria and fungus will adversely affect cellular metabolism and inhibit cell growth. The nano silver suppresses respiration, basal metabolism of electron transfer system, and transport of substrate in the microbial cell membrane. The nano silver inhibits multiplication and growth of those bacteria and fungi which cause infection, odor, itchiness and sores. Nano Silver can be applied to range of other healthcare products such as dressings for burns, scald, skin donor and recipient sites; acne and cavity wounds; and female hygiene products - panty liners, sanitary towels and pants.
\end{abstract}

Keywords: Nanotechnology, Nano Silver, bactericidal, fungicidal, Silver

\section{Introduction}

Nanotechnology is a rapidly growing science of producing and utilizing nano-sized particles that measure in nanometers $(1 \mathrm{~nm}=1$ billionth of a meter). People use nanotechnology and nanomaterials in everyday life because of their unique or rather different chemical and physical properties. It is common to find various products with nanomaterials on the market. Very often we find hydrophobic coatings for cars, self-cleaning surfaces preventing dirt accumulation or $\mathrm{T}$-shirts that remain fresh and odour free for an extended period of time [1]. Unique nanomaterial properties steam from their size i.e. particles between 1 and 100 nanometers [2]. On this size scale insulating materials can become conductive, water-insoluble materials can become soluble and etc. Also nanotechnology often means that you need only small amounts of raw nanomaterials to add a desired feature to your product. This is an attractive feature both from environmental and business perspective. People should use nanomaterials as any other advanced technology, i.e. responsibly so that offered benefits would not become risks [3]. Silver nanoparticles have attracted increasing attention for the wide range of applications in biomedicine. Silver nanoparticles, generally smaller than $100 \mathrm{~nm}$ and contain 20-15,000 silver atoms, have distinct physical, chemical and biological properties compared to their bulk parent materials. The optical, thermal, and catalytic properties of silver nanoparticles are strongly influenced by their size and shape [4]. Additionally, owning to their broad-spectrum antimicrobial ability, silver nanoparticles have also become the most widely used sterilizing nanomaterials in consuming and medical products, for instance, textiles, food storage bags, refrigerator surfaces, and personal care products [5, 6]. Applications of $\mathrm{Ag}$ nanoparticles in various sciences are schematically shown in Figure 1.

Corresponding author: Sh.Ahmadi, Department of Science, Payame Noor University (PNU), Tehran, Iran.

E-mail: sh.ahmadi@pnu.ac.ir

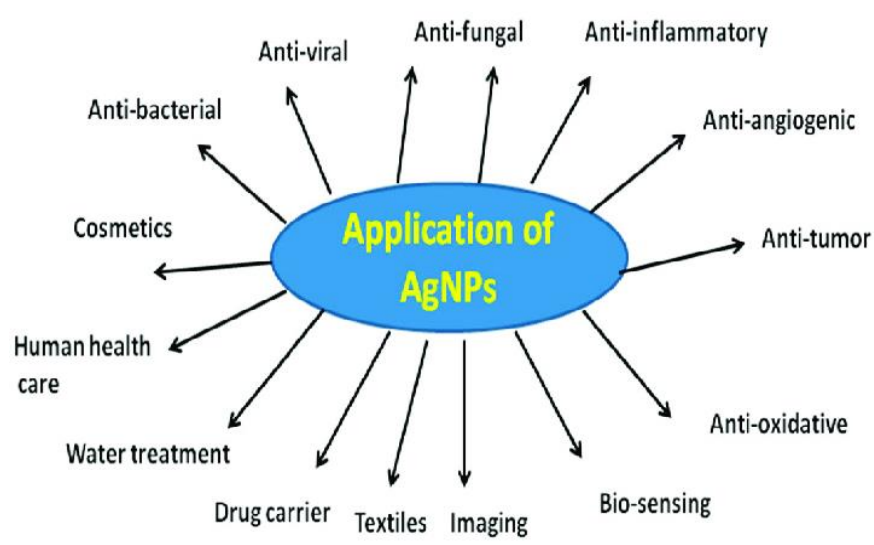

Figure 1: Application of Silver nanoparticles in various Science [27].

\section{Silver and Nano silver}

Silver (Ag) is one of the basic elements that make up our planet. It is a rare but naturally occurring element, slightly harder than gold and very ductile and malleable. Pure silver has the highest electrical and thermal conductivity of all metals and has the lowest contact resistance. It may be released into the air and water through natural processes such as the weathering of rocks or by human activities like processing of ores, cement manufacture and the burning of fossil fuel. Rain may wash silver out of soil into the ground- water. Silver can be present in four different oxidation states: $\mathrm{Ag}^{0}, \mathrm{Ag}^{+}, \mathrm{Ag}^{2+}$ and $\mathrm{Ag}^{3+}$. The former two are the most abundant ones; the latter two are unstable in the aquatic environment the free silver ion is $\mathrm{Ag}^{+}$. In the environment, silver is found as a monovalent ion together with sulfide, bicarbonate or sulfate or more complex with chlorides and sulfates adsorbed onto particulate matter in the aqueous phase [7].

Nano silver inherits many of the properties from silver and its one of the useful materials that can be applied in multiple industries. It has a high electrical and heat conductivity. Likewise 
it can effectively control growth of over 650 species of bacterial, fungi and algae by releasing silver ions [1]. Nano silver is not an allergen. When a size of a silver nanoparticle is below a few nanometers it becomes fluorescent. Furthermore, nano silver is an efficient light scattered. All of these properties enable us to use nano silver in medical, household, hygiene products as well as in textiles, electronics, solar cells, water filters, industrial fluids, farms and many other areas[2].

Identical quantity of silver and nano silver would have different surface area. For example, silver spheres with four times smaller diameter have four times higher surface area [3]. Silver ions are released in a different manner from nano silver compared to silver salts and bulk silver[4]:

1. Silver ions emerge faster from nano silver than from regular silver.

2. Highly soluble silver salts will have high pace yet short duration for silver ion emission.

3. Ion release from nano silver is slower and more consistent over longer periods of time.

\subsection{Properties of silver Nanoparticles}

When silver nanoparticles are exposed to a specific wavelength of light, the oscillating electromagnetic field of the light induces a collective coherent oscillation of the free electrons, which causes a charge separation with respect to the ionic lattice, forming a dipole oscillation along the direction of the electric field of the light. The amplitude of the oscillation reaches maximum at a specific frequency, called surface plasmon resonance (SPR) [5]. The absorption and scattering properties of silver nanoparticles can be changed by controlling the particle size, shape and refractive index near the particle surface. For example, smaller nanoparticles mostly absorb light and have peaks near $400 \mathrm{~nm}$, while larger nanoparticles exhibit increased scattering and have peaks that broaden and shift towards longer wavelengths. Besides, the optical properties of silver nanoparticles can also change when particles aggregate and the conduction electrons near each particle surface become delocalized $[5,6]$.

Also, $\mathrm{Ag}$ was used as an antiseptic from ancient times. In principle pure silver, silver salts, silver and silica mixtures, nano silver, silver colloids or other silver compounds have a similar mode of operation. All of these substances release silver ions to liquid phase. Some of these materials release silver ions abruptly but for a short period of time whilst others release silver ions slower but over a longer time scale. Released silver ions interact strongly with nitrogen, phosphorus and sulfur containing compounds in bacteria, algae and fungi $[7,8]$. This is how silver efficiently inhibits growth of these microorganisms. Silver as any other material can be useful and it may possess risks - all of which depends on how it is used and how it is managed [9]. Therefore, proper and professional quantity and quality control is essential for best results. Manufacturers use silver often for an electrical contact, because as a material it is highly conductive. Applications range from electronics, automotives to energy industry as well as many others. For instance, one can manufacture electrical contacts using magnetron sputtering, silver pastes, electrolysis, ink-jet printing and other technologies. In particular, there is a growing demand for transparent, flexible and conductive electrical contacts. LG uses such electrodes in roll-up TV screen, which they released recently $[10,11]$.

\subsection{Silver toxicity and applications}

When using nano silver or any other silver compound for formulating new or existing products it is crucial to assess possible environmental impact and possible interactions with living beings [10]. Scientists has undertaken an extensive study to measure how nano silver and silver salts affect water invertebrates, fish, water plants, algae, microorganisms, rabbits and rats. They have observed most pronounced effect for invertebrates, algae and microorganisms. Rabbits and rats were injected intravenously, ingested orally and dermally exposed to nano silver. Scientists has found only minor fraction of nano silver in kidneys, because tested animals excreted most of the orally consumed nano silver. No dermal or eye sensitization was observed even at an excessive dosage[12]. Manufacturers use silver nanoparticles in electrical applications due to their good electrical conductivity. Nano silver has a different melting point compared to macroscopic silver so it a good material for inks and pastes. Nano silver based ink can be applied to plastic surfaces or other materials prone to deformation at higher temperatures. For instance, manufacturer of radio frequency identification devices (RFID) uses nano silver based conductive inks for printing on plastic stickers for clothes and flexible electronics [13, 14].

Peptide capped silver nanoparticle for colorimetric sensing has been mostly studied in past years, which focus on the nature of the peptide and silver interaction and the effect of the peptide on the formation of the silver nanoparticles. Besides, the efficiency of silver nanoparticles based fluorescent sensors can be very high and overcome the detection limits $[15,16]$.

Silver nanoparticles are widely used as probes for surfaceenhanced Raman scattering (SERS) and metal-enhanced fluorescence (MEF). Compared to other noble metal nanoparticles, silver nanoparticles exhibit more advantages for probe, such as higher extinction coefficients, sharper extinction bands, and high field enhancements [17, 18]].

Silver nanoparticles are most widely used sterilizing nanomaterial in consuming and medical products, for instance, textiles, food storage bags, refrigerator surfaces, and personal care products $[19,20]$. It has been proved that the antibacterial effect of silver nanoparticles is due to the sustained release of free silver ions from the nanoparticles [21].

Silver nanoparticles have been demonstrated to present catalytic redox properties for biological agents such as dyes, as well as chemical agents such as benzene. The chemical environment of the nanoparticle plays an important role in their catalytic properties. In addition, it is important to know that complicated catalysis takes place by adsorption of the reactant species to the catalytic substrate. When polymers, complex ligands, or surfactants are used as the stabilizer or to prevent coalescence of the nanoparticles, the catalytic ability is usually decreased due to reduced adsorption ability. In general, silver nanoparticles are mostly used with titanium dioxide as the catalyst for chemical reactions [22, 23].

\subsection{Synthesis methods and mechanism of Antibacterial Action of Silver nanoparticles}

Nano-silver is often stated to be a relatively new and a different type of silver with different chemical and physical properties. Nano-silver particles are generated by several methods from metallic silver and are generally used in food, consumer products and medical products because of their antibacterial activity [24]. Table 1 shows a small number of recent studies, also the size variability of the green synthesized AgNPs from plant and microbial origins. It is evident from Table 1 that the size of synthesized Ag-NPs ranges from 50 to $100 \mathrm{~nm}$ in most of the listed studies. Because of its small size, nanoparticles can potentially pass through biological membranes and reach more and different organs and tissues in the body where the silver can exert its antibacterial effects $[25,26]$. Since the prevailing view is that silver is relatively non-toxic, additional toxic effects, such as generation of oxidative stress, of nano-silver can be attributed to the nano-characteristics of the particle, such as the large surface area and associated high 
reactivity [27]. A comparison of the antibacterial mechanism of silver ions and silver nanoparticles is shown in Figure 2.

Table 1: Few works of recent green synthesis of Ag-NPs.[28]

\begin{tabular}{|c|c|c|c|c|}
\hline $\begin{array}{l}\text { Sl. } \\
\text { no. }\end{array}$ & Author & Reducing agent & Particle characteristics & Remarks \\
\hline 1 & Kathiraven et al. & $\begin{array}{l}\text { Filtered aqueous extract of Caulerpa } \\
\text { racemosa marine algae }\end{array}$ & $\begin{array}{l}\text { Size- } 5-25 \mathrm{~nm} \text { Shape-sph, tri. } \\
\text { Structure-FCC }\end{array}$ & Antibacterial action against $P$. mirabilis and $S$. aureus \\
\hline 2 & John De Britto et al. & $\begin{array}{l}\text { Aqueous filtrate of Pteris argyraea, } \\
\text { Pteris confuse, and Pteris biaurita }\end{array}$ & - & $\begin{array}{l}\text { Antibacterial action against Shigella boydii, Shigella } \\
\text { dysenteriae, S. aureus, Klebsiella vulgaris, and Salmonella } \\
\text { typhi }\end{array}$ \\
\hline 3 & Sant et al. & $\begin{array}{l}\text { Aqueous filtrate of Adiantum } \\
\text { philippense L. }\end{array}$ & $\begin{array}{l}\text { Size-10-18 nm Shape-anisotropic } \\
\text { Structure-FCC Nature-MD }\end{array}$ & $\begin{array}{l}\text { Ag-NPs from medicinally important plants opens } \\
\text { spectrum of medical applications }\end{array}$ \\
\hline 4 & Bhor et al. & $\begin{array}{l}\text { Aqueous filtrate of Nephrolepis exaltata } \\
\text { L fern }\end{array}$ & $\begin{array}{l}\text { Size-avg } 24.76 \mathrm{~nm} \text { Shape-sph. } \\
\text { Structure-FCC }\end{array}$ & Antibacterial against many human and plant pathogens \\
\hline 5 & Ajitha et al. & $\begin{array}{l}\text { Filtered aqueous extract of Tephrosia } \\
\text { purpurea leaf powder }\end{array}$ & $\begin{array}{l}\text { Size- } 20 \mathrm{~nm} \text { Shape- } 5 \mathrm{ph} . \\
\text { Structure-FCC }\end{array}$ & $\begin{array}{l}\text { Antimicrobial agents against Pseudomonas spp. and } \\
\text { Penicillium spp. }\end{array}$ \\
\hline 6 & $\begin{array}{l}\text { Rahimi-Nasrabadi } \\
\text { et al. }\end{array}$ & $\begin{array}{l}\text { Methanolic extract and essential oil of } \\
\text { Eucalyptus leucoxylon leaf }\end{array}$ & $\begin{array}{l}\text { Size- } 50 \mathrm{~nm} \text { Shape-sph. } \\
\text { Structure-FCC }\end{array}$ & Ag-NPs with biomedical potential \\
\hline 7 & Bagherzade et al. & $\begin{array}{l}\text { Aqueous extract of saffron (Crocus } \\
\text { sativus L.) }\end{array}$ & Size- $12-20 \mathrm{~nm}$ & $\begin{array}{l}\text { Inhibiting activity against Escherichia coli, Pseudomonas } \\
\text { aeruginosa, Klebsiella pneumonia, Shigella flexneri, and } \\
\text { Bacillus subtilis }\end{array}$ \\
\hline 8 & Ashokkumar et al. & $\begin{array}{l}\text { Filtered aqueous extract of Abutilon } \\
\text { indicum leaf }\end{array}$ & $\begin{array}{l}\text { Size-7-17 nm Shape-sph. } \\
\text { Structure-FCC }\end{array}$ & $\begin{array}{l}\text { Antimicrobial action against S. typhi, E. coli, S. aureus, B. } \\
\text { subtilis }\end{array}$ \\
\hline 9 & Tagad et al. & Locust bean gum polysaccharide. & Size- $-18-51 \mathrm{~nm}$ & $\begin{array}{l}\text { Stability: } 7 \text { months, Ag-NPs served in development of } \\
\mathrm{H}_{2} \mathrm{O}_{2} \text { sensor }\end{array}$ \\
\hline 10 & Yasin et al. & Filtered aqueous extract of Bamboo leaf & $\begin{array}{l}\text { Size }-13 \pm 3.5 \mathrm{~nm} \text { Shape-nearly sph. } \\
\text { Structure-cryst }\end{array}$ & Antibacterial to $E$. coli and S. aureus \\
\hline 11 & $\begin{array}{l}\text { Sadeghi and } \\
\text { Gholamhoseinpoor }\end{array}$ & $\begin{array}{l}\text { Methanol extracted aqueous filtrate of } \\
\text { Ziziphora temuior leaf }\end{array}$ & $\begin{array}{l}\text { Size- } 8-40 \mathrm{~nm} \text {. Shape-5ph. } \\
\text { Structure-FCC }\end{array}$ & Stability: $6-12 \mathrm{pH}$ range \\
\hline 12 & Chen et al. & Chitosan biopolymer & $\begin{array}{l}\text { Size- } 218.4 \mathrm{~nm} \text { Shape-oval and } \\
\text { sph. Nature-Ag/chitosan nano } \\
\text { hybrids }\end{array}$ & $\begin{array}{l}\text { Antimicrobial to E. coli, S. choleraesuis, S. aureus, and B. } \\
\text { subtilis }\end{array}$ \\
\hline 13 & Mondal et al. & $\begin{array}{l}\text { Saline washed, filtered aqueous extract } \\
\text { of Parthenium hysterophorus root }\end{array}$ & Shape-spherical & Potential larvicidal for Culex quinquefasciatus \\
\hline 14 & Nalwade et al. & $\begin{array}{l}\text { Aqueous filtrate of Cheilanthes forinosa } \\
\text { Forsk leaf }\end{array}$ & $\begin{array}{l}\text { Size- } 26.58 \mathrm{~nm} \text { Shape-sph. } \\
\text { Structure-FCC }\end{array}$ & $\begin{array}{l}\text { Antibacterial action against S. aureus and Proteus } \\
\text { morgani }\end{array}$ \\
\hline 15 & Singh et al. & Lantana camara & $48.1 \mathrm{~nm}$ & $\begin{array}{l}\text { Antimicrobial to E coli and S. aureus. Leakage due to cell } \\
\text { wall rupturing }\end{array}$ \\
\hline 16 & Vimala et al. & Leaf and fruit of Couroupita guianensis & Cubic size $10-45 \mathrm{~nm} 5-15 \mathrm{~nm}$ & $\begin{array}{l}\text { Water soluble phenolic compounds as reducing and } \\
\text { stabilizing agent larvicidal to Aedes aegypti extensive } \\
\text { mortality rate (LC90 } 5.65 \mathrm{ppm} \text { ) }\end{array}$ \\
\hline 17 & Cheng et al. & Chondroitin sulfate & Size-20 nmShape-sph & $\begin{array}{l}\text { Stable for } 2 \text { months, Served as nano carrier for drug } \\
\text { delivery }\end{array}$ \\
\hline 18 & Sadeghi et al. & $\begin{array}{l}\text { Filtered aqueous-methanol extract of } \\
\text { Pistacia atlantica seed powder }\end{array}$ & $\begin{array}{l}\text { Size-10-50 nm Shape-5ph. } \\
\text { Structure-FCC }\end{array}$ & $\begin{array}{l}\text { Stability: } 7-11 \mathrm{pH} \text { range. Antibacterial affect against } S \text {. } \\
\text { aureus. }\end{array}$ \\
\hline 19 & Zhang et al. & $\begin{array}{l}\text { Lactobacillus fermentum. LMG } 8900 \\
\text { cells }\end{array}$ & $\begin{array}{l}\text { Size }-6 \mathrm{~nm} \text { Shape- } 5 \text { ph. Structure- } \\
\text { FCC }\end{array}$ & $\begin{array}{l}\text { Stable for } 3 \text { months. Resist growth of E. coli, S. aureus and } \\
\text { P. aeruginosa Act as promising anti-biofouling agent }\end{array}$ \\
\hline 20 & Das et al. & Mycelia of Rhizopus oryzae & $\begin{array}{l}\text { Size- } 15 \mathrm{~nm} \text { Shape-sph. } \\
\text { Structure-FCC }\end{array}$ & $\begin{array}{l}\text { Stable for } 3 \text { months, Antimicrobial to } E \text {. coli and } B \text {. } \\
\text { subtilis, Used for treating contaminated water and } \\
\text { adsorption of pesticides }\end{array}$ \\
\hline 21 & El-Rafie et al. & $\begin{array}{l}\text { Crude hot water soluble polysaccharide } \\
\text { extracted from different marine algae }\end{array}$ & Size-7-20 nm Shape-sph & $\begin{array}{l}\text { Stability: } 6 \text { months,Ag-NPs treated cotton fibers } \\
\text { antibacterial to E coli and S. aureus }\end{array}$ \\
\hline 22 & Suresh et al. & $\begin{array}{l}\text { Filtered aqueous extract of Delphinium } \\
\text { denudatum root powder }\end{array}$ & $\begin{array}{l}\text { Size- } 85 \mathrm{~nm} \\
\text { Shape-sph. Structure-FCC Nature- } \\
\text { PD }\end{array}$ & $\begin{array}{l}\text { Anti-bacterial against S. aureus, B. cereus, E. coli and } P \text {. } \\
\text { aeruginos Larvicidal to A. aegypti }\end{array}$ \\
\hline 23 & Zuas et al. & $\begin{array}{l}\text { Filtered aqueous extract of Myrmecodia } \\
\text { pendan plant }\end{array}$ & $\begin{array}{l}\text { Size-10-20 nm Shape-sph. } \\
\text { Structure-FCC }\end{array}$ & Promising therapeutic value \\
\hline 24 & Vijaykumar et al. & $\begin{array}{l}\text { Aqueous extract of Boerhaavia diffusa } \\
\text { plant powder. }\end{array}$ & $\begin{array}{l}\text { Size- } 25 \mathrm{~nm} \text { Shape-sph. } \\
\text { Structure-FCC, Cub }\end{array}$ & $\begin{array}{l}\text { Antibacterial to fish pathogens A. hydrophila, } F \text {. } \\
\text { branchiophilum, P. fluorescens }\end{array}$ \\
\hline 25 & Elumalai et al. & Filtered coconut water & $\begin{array}{l}\text { Size- } 70-80 \mathrm{~nm} \text { Structure-FCC } \\
\text { Nature-PD }\end{array}$ & Metabolites and proteins served as capping agents \\
\hline
\end{tabular}

Note: PD-Polydispersed, MD-Monodispersed, WD-Well Dispersed, Cryst-Crystalline. FCC-Face centered cubic; Tri-Triangular; Sph-Spherical; cryst-crystalline; Cub-cubic.

It can be stated that AgNPs have gained remarkable interest, as they possess a wide range of applications in different fields including material science, biotechnology, and environmental and medical fields. Attributable to their distinctive physiochemical properties, AgNPs have been extensively used against bacteria, fungi, virus, leishmania, malaria, and neoplastic cells. Moreover, AgNPs have been prepared by different procedures such as chemical, physical, and biological methods. In biosynthetic methods, the potential of nature-gifted environmental-friendly reducers and stabilizers has been explored. The biogenic method is considered eco-friendly and handy to be applied in various realms, for instance, medical, cosmetic, and pharmaceutical fields. There still exist some open questions regarding silver-based nanotechnology, and each synthetic method has critical limitations which require special 
attention to eradicate. Furthermore, the toxic effects of AgNPs targeting from microorganisms to higher organisms including human is another interesting aspect that has also been outlined in this review [29].

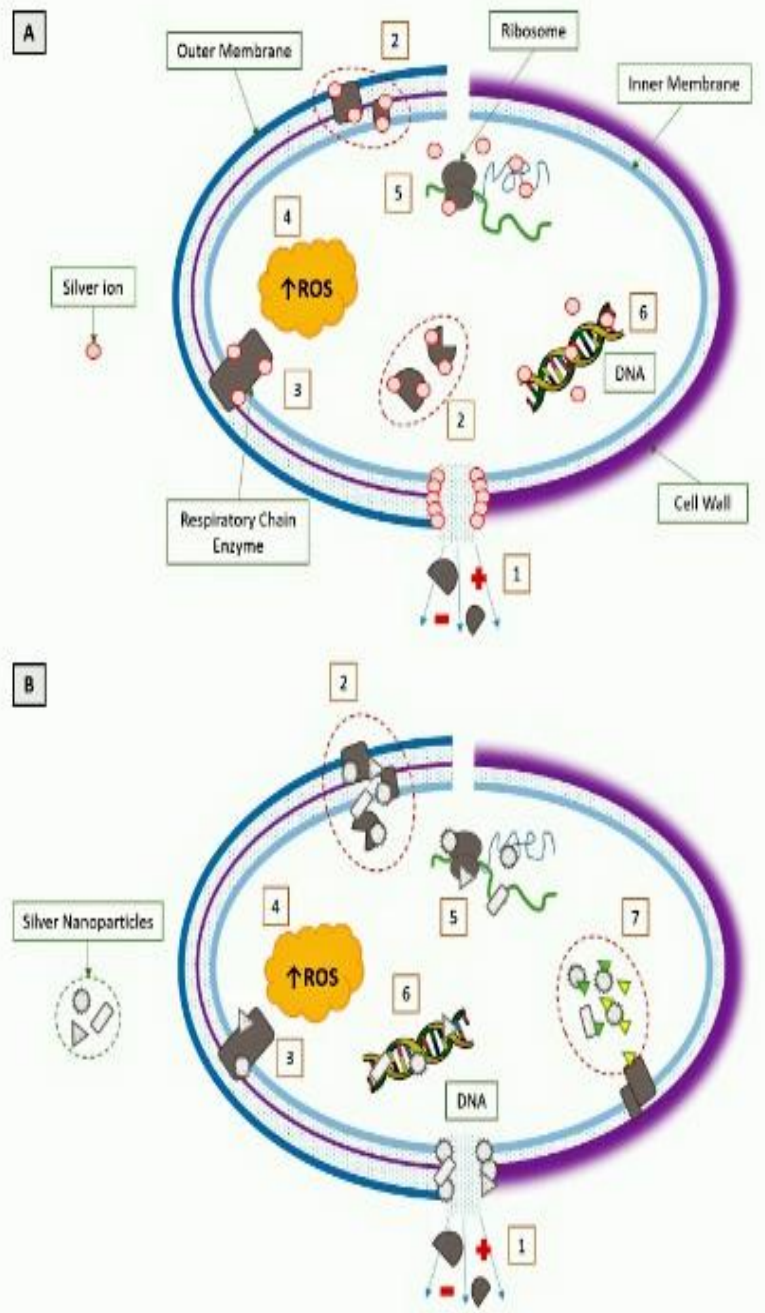

Figure 2. A comparison of the silver ions (A) and silver nanoparticles' (B) mode of action to Gram negative (left) and Gram-positive (right) bacteria. (1) Pore formation; metabolites and ions leakage (shown as plus and minus in the figure above) (2) Denaturation of structural and cytoplasmic proteins; enzymes inactivation. (3) Inactivation of respiratory chain enzymes. (4) Increase of intracellular reactive oxygen species (ROS) concentration. (5) Interaction with ribosome. (6) Interaction with nucleic acids. (7) Inhibition of signal transduction [30].

Although reports regarding the potential of AgNPs against cancer, malaria and leishmania, and other human diseases are available, it will be a great revolution to find out the potential role of AgNPs against world's leading diseases with high mortality like AIDs and chronic hepatitis, which still need proper treatment[29]. The biological systems including bacteria, fungi, and plants maintain a tight regulation of various metabolic machineries such as photosynthesis, respiration, and transport mechanism for several ions across membranes, and cell architecture (organization of lipids and proteins in the cell membrane and other endo membranes and cell wall). How AgNPs could take a promising part in regulating these metabolic pathways operating simultaneously will be an interesting facet of AgNPs mechanism of action which awaits elucidation. Furthermore, as evident from many studies, cancer cells use glucose, glutamine, asparagine (in some cases), lipids, and proteins as fuels for their uncontrolled proliferation. Now the question is whether
AgNPs prevent the growth of cancer cells either by activation of the expression of glucosidase, lipase, or proteinase enzymes or by clinging to the mitotic and meiotic apparatus during cell division to block the whole metabolic machinery of the abnormal cells. For a certain type of cancer like acute lymphoblastic leukemia where asparagine is the main nutrient reservoir, if AgNPs control its levels by regulating the expression of Lasparaginase, then $\mathrm{pH}$ change (i.e., from neutral to acidic) of the medium (blood) would occur which could cause hindrance to the cancer cell proliferation. In short, in-depth handy mechanistic studies are required to fill these gaps [30].

\section{Summary and Conclusions}

Having a tremendous surface area and small particle size, nanoparticles can make potential interactions with membrane surfaces and can easily translocate and become distributed throughout the human body. Taking into account their physicochemical and biological properties, it is likely that nanoparticles possess unique toxicity mechanisms. It remains to be determined whether silver nanoparticles and other nanoparticles will introduce new mechanisms of injury from which new pathologies may result. Finally, for silver, whether nano-sized or not, there are always the problems of argyria and argyrosis in humans and eutrophication in the environment.

\section{Ethical issue}

Authors are aware of, and comply with, best practice in publication ethics specifically with regard to authorship (avoidance of guest authorship), dual submission, manipulation of figures, competing interests and compliance with policies on research ethics. Authors adhere to publication requirements that submitted work is original and has not been published elsewhere in any language.

\section{Competing interests}

The authors declare that there is no conflict of interest that would prejudice the impartiality of this scientific work.

\section{Authors' contribution}

All authors of this study have a complete contribution for data collection, data analyses and manuscript writing.

\section{References}

[1] Dakal TC, Kumar A, Majumdar RS, Yadav V. Mechanistic basis of antimicrobial actions of silver nanoparticles. Frontiers in microbiology. 2016;7:1831.

[2] Evanoff DD, Chumanov G. Size-controlled synthesis of nanoparticles. 2. Measurement of extinction, scattering, and absorption cross sections. The Journal of Physical Chemistry B. 2004;108(37):13957-62.

[3] Oberdörster G, Oberdörster E, Oberdörster J. Nanotoxicology: an emerging discipline evolving from studies of ultrafine particles. Environ Health Perspect 113: 823-839. 2005.

[4] Mitrano DM, Rimmele E, Wichser A, Erni R, Height M, Nowack B. Presence of nanoparticles in wash water from conventional silver and nano-silver textiles. ACS nano. 2014;8(7):7208-19.

[5] Zaheer Z. Biogenic synthesis, optical, catalytic, and in vitro antimicrobial potential of Ag-nanoparticles prepared using Palm date fruit extract. Journal of Photochemistry and Photobiology B: Biology. 2018;178:584-92.

[6] Butler KS, Peeler DJ, Casey BJ, Dair BJ, Elespuru RK. Silver nanoparticles: correlating nanoparticle size and cellular uptake with genotoxicity. Mutagenesis. 2015;30(4):577-91.

[7] Mijnendonckx K, Leys N, Mahillon J, Silver S, Van Houdt R. Antimicrobial silver: uses, toxicity and potential for resistance. Biometals. 2013;26(4):609-21.

[8] Silver S, Phung LT, Silver G. Silver as biocides in burn and wound dressings and bacterial resistance to silver compounds. 
Journal of Industrial Microbiology and Biotechnology. 2006;33(7):627-34.

[9] Fox CL, Modak SM. Mechanism of silver sulfadiazine action on burn wound infections. Antimicrobial agents and chemotherapy. 1974;5(6):582-8.

[10] SUN J-h, ZHU Q-d, YAN Z-j, LU H-m, WANG H-r. A review of research and application of AGNPS model. Advances in Water Science. 2009;6.

[11] Zhang X-F, Liu Z-G, Shen W, Gurunathan S. Silver nanoparticles: synthesis, characterization, properties, applications, and therapeutic approaches. International journal of molecular sciences. 2016;17(9):1534.

[12] Oomen AG, Steinhäuser KG, Bleeker EA, van Broekhuizen F, Sips A, Dekkers S, et al. Risk assessment frameworks for nanomaterials: Scope, link to regulations, applicability, and outline for future directions in view of needed increase in efficiency. NanoImpact. 2018;9:1-13.

[13] Beyene HD, Werkneh AA, Bezabh HK, Ambaye TG. Synthesis paradigm and applications of silver nanoparticles (AgNPs), a review. Sustainable materials and technologies. 2017;13:18-23.

[14] Larpant N, Pham AD, Shafaat A, Gonzalez-Martinez JF, Sotres J, Sjöholm J, et al. Sensing by wireless reading $\mathrm{Ag} / \mathrm{AgCl}$ redox conversion on RFID tag: universal, battery-less biosensor design. Scientific reports. 2019;9(1):1-9.

[15] Ge S, Zhao J, Ma G. Monochromatic Photolysis to Generate Silver Quantum Clusters in Polymer Matrices with Efficiently Antibio Property. Langmuir. 2020;36(15):4088-97.

[16] Makwana BA, Darjee S, Jain VK, Kongor A, Sindhav G, Rao MV. A comparative study: Metal nanoparticles as fluorescent sensors for biomolecules and their biomedical application. Sensors and Actuators B: Chemical. 2017;246:68695.

[17] Geddes CD, Cao H, Gryczynski I, Gryczynski Z, Fang J, Lakowicz JR. Metal-enhanced fluorescence (MEF) due to silver colloids on a planar surface: Potential applications of indocyanine green to in vivo imaging. The Journal of Physical Chemistry A. 2003;107(18):3443-9.

[18] Kneipp K, Wang Y, Kneipp H, Perelman LT, Itzkan I, Dasari RR, et al. Single molecule detection using surfaceenhanced Raman scattering (SERS). Physical review letters. 1997;78(9): 1667.

[19] Iravani S, Korbekandi H, Mirmohammadi SV, Zolfaghari B. Synthesis of silver nanoparticles: chemical, physical and biological methods. Research in pharmaceutical sciences. 2014;9(6):385

[20] Nowack B, Krug HF, Height M. 120 years of nanosilver history: implications for policy makers. ACS Publications; 2011.

[21] Ahmadi S, Fazilati M, Mousavi SM, Nazem H. Antibacterial/fungal and anti-cancer performance of green synthesized $\mathrm{Ag}$ nanoparticles using summer savory extract. Journal of Experimental Nanoscience. 2020;15(1):363-80.

[22] Dong X-Y, Gao Z-W, Yang K-F, Zhang W-Q, Xu L-W. Nanosilver as a new generation of silver catalysts in organic transformations for efficient synthesis of fine chemicals. Catalysis Science \& Technology. 2015;5(5):2554-74.

[23] Sarkar D, Khare D, Kaushal A, Acharya C, Bahadur J, Prakash J, et al. Green and scalable synthesis of nanosilver loaded silica microparticles by spray-drying: application as antibacterial agent, catalyst and SERS substrate. Applied Nanoscience. 2019;9(8):1925-37.

[24] Abbasi E, Milani M, Fekri Aval S, Kouhi M, Akbarzadeh A, Tayefi Nasrabadi $H$, et al. Silver nanoparticles: synthesis methods, bio-applications and properties. Critical reviews in microbiology. 2016;42(2):173-80.
[25] Prabhu S, Poulose EK. Silver nanoparticles: mechanism of antimicrobial action, synthesis, medical applications, and toxicity effects. International nano letters. 2012;2(1):32.

[26] Samberg ME, Orndorff PE, Monteiro-Riviere NA. Antibacterial efficacy of silver nanoparticles of different sizes, surface conditions and synthesis methods. Nanotoxicology. 2011;5(2):244-53.

[27] Chen X, Schluesener HJ. Nanosilver: a nanoproduct in medical application. Toxicology letters. 2008;176(1):1-12.

[28] Akter M, Sikder MT, Rahman MM, Ullah AA, Hossain KFB, Banik S, et al. A systematic review on silver nanoparticlesinduced cytotoxicity: Physicochemical properties and perspectives. Journal of advanced research. 2018;9:1-16.

[29] Wijnhoven SW, Peijnenburg WJ, Herberts CA, Hagens WI, Oomen AG, Heugens EH, et al. Nano-silver-a review of available data and knowledge gaps in human and environmental risk assessment. Nanotoxicology. 2009;3(2):109-38.

[30] Kędziora A, Speruda M, Krzyżewska E, Rybka J, Łukowiak A, Bugla-Płoskońska G. Similarities and differences between silver ions and silver in nanoforms as antibacterial agents. International journal of molecular sciences. 2018;19(2):444. 